\title{
POMOC FINANSOWA DLA KRAJÓW STREFY EURO PODJĘTA W REAKCJI NA KRYZYS ZADLUŻENIA
}

\author{
FINANCIAL AID FOR EUROZONE COUNTRIES \\ TAKEN IN RESPONSE TO DEBT CRISIS
}

\begin{abstract}
Crisis which began in 2007 in the United States caused problems in some Eurozone countries. Due to low interest rates and cheap credit mortgage bubble was inflated. Many international financial institutions were strongly engaged in home loans market and market of derivatives linked with mortgages, so when mortgage market in USA broke down many of those institutions lost financial stability and some of them bankrupted. Investors retreated their capital from risky instruments and several bonds and put it in more secure assets. It caused credit crunch and liquidity crunch in international financial markets, which had impact on financial situation of some European countries. Good example is Greece budget was strongly basing on cheap loans, so when liquidity crunch occurred they appeared in shadow of bankruptcy. Other countries like Ireland or Spain had problems due to their own mortgage bubbles and their budgets broke because they had to rescue financial institutions. European Union created several instruments to help those countries along with IMF, but not in all cases assistance was well used. Ireland came back to way of prosperity, but Greece is still struggling to avoid bankruptcy and their budget is way off balance. It would be better if European countries abandoned their political objectives, let Greece broke and come back to drachma to avoid endless loses and, in the long run, lower uncertainty on the market.
\end{abstract}

Keywords: financial crisis, Eurozone, financial aid, mortgage bubble

JEL classification: E32, E63, F34, F44, F45

\section{Wstęp}

Kryzys gospodarczy, który wybuchł w roku 2007 w Stanach Zjednoczonych, spowodował szereg negatywnych konsekwencji nie tylko w jego epicentrum. Skutki załamania gospodarczego w USA silnie odczuły również państwa europejskie, głównie za sprawą silnych powiązań istniejących między instytucjami finansowymi. Wybuch kryzysu w Europie zwiększył prawdopodobieństwo bankructwa części gospodarek, co spowodowało, że część krajów uznano

* Katedra Makroekonomii, Uniwersytet Łódzki, pawel.matysiak@uni.lodz.pl 
za głównych winowajców ogarniających Europę problemów. Pomijano jednak fakt, że instytucje europejskie nie wywiązały się w odpowiedni sposób ze swojej roli i stworzyły warunki do rozwoju problemów. Kiedy koniunktura była dobra, pomijano kwestię narastających długów. Uznano bowiem, że dzięki udziałowi w strefie euro państwom tym nie zagraża destabilizacja. Rolę instytucji europejskich dostrzeżono dopiero w momencie, gdy kryzys rozprzestrzenił się na kontynencie. Przyjęto wtedy, że ich zadaniem jest pomoc finansowa krajom pogrążonym w kryzysie.

Celem artykułu jest przybliżenie rozwoju kryzysu finansowego z roku 2007 w USA, przedstawienie mechanizmu transmisji kryzysu do Europy, analiza jego wpływu na sytuację gospodarczą wybranych krajów oraz przedstawienie procesu uruchamiania poszczególnych programów pomocowych oraz ich wysokości. Podjęta została również próba odpowiedzi na pytanie, czy na pewno wszystkie kraje są równie winne perturbacjom w Europie, a także próba oceny zasadności udzielanej pomocy. W tym celu dokonano analizy porównawczej sytuacji poszczególnych krajów przed wystąpieniem kryzysu oraz analizę skutków, jakie przyniosło wprowadzenie środków pomocowych.

\section{Geneza i rozwój kryzysu finansowego w Stanach Zjednoczonych oraz jego transmisja do krajów strefy euro}

Na wybuch kryzysu w Europie wpływ miało wiele czynników. Najczęściej wskazywanym powodem jest transmisja kryzysu finansowego ze Stanów Zjednoczonych przy użyciu dwóch wyszczególnionych elementów finansowego „kanału zarażania”. Pierwszym z nich był spadek płynności na rynku międzybankowym, a drugim korekta wyceny ryzyk ${ }^{1}$. Efekt zarażania nie został jednoznacznie opisany w literaturze. Istnieje bowiem wiele definicji, a poszczególni autorzy wyróżniają zróżnicowane kanały transmisyjne. Jednym z przyjętych kanałów transmisji kryzysów jest wspomniany wyżej kanał finansowy², do którego można zaliczyć zarówno spadek płynności na rynku międzybankowym, jak i korektę wyceny ryzyk. Ponadto w transmisji kryzysu 2007 dostrzec można było elementy kanału zachowań stadnych, w których to część podmiotów podejmuje zbliżone decyzje, sugerując się zachowaniami innych podmiotów i chęcią gry „z rynkiem”, a nie

${ }^{1}$ A. Chudik, M. Fratzscher, Identifying The Global Transmission of the 2007-09 Financial Crisis in a GVAR Model, ECB Working Paper Series No. 1285, 2011, s. 5 i nn.

2 S. Mazurek, Ścieżki międzynarodowej transmisji kryzysów, [w:] Koniunktura gospodarcza. Od bańki internetowej do kryzysu subprime, red. J. Czech-Rogosz, J. Pietrucha, R. Żelazny, Wydawnictwo C.H. Beck, Warszawa 2009, [cyt. za:] P. Gabrielczak, Rola kanału handlowego i finansowego w zarażeniu państw rozwiniętych i rozwijających się, Studia i prace Wydziału Nauk Ekonomicznych i Zarządzania, 3(41), 2015, s. 28. 
„przeciw rynkowi”, ze względu na pozornie większe bezpieczeństwo oraz większą opłacalność takiej strategii ${ }^{3}$.

Wybuch kryzysu w Stanach Zjednoczonych był konsekwencją działań zarówno Rezerwy Federalnej, jak i podmiotów prywatnych. Rezerwa Federalna po atakach 11 września 2001 roku znacząco obniżyła stopy procentowe, przez co banki mogły dużo taniej pożyczać pieniądze. Zwiększona podaż pieniądza, która była skutkiem polityki niskich stóp procentowych, doprowadziła do wzrostu ilości kredytów przeznaczanych na zakup domów, co przełożyło się na powstanie „bańki spekulacyjnej” na rynku nieruchomości. Początkowo kredyty były udzielane w znacznej mierze osobom, które posiadały zdolność kredytową, jednakże kiedy pierwotny rynek się nasycił, banki zaczęły udzielać większej ilości kredytów subprime, czyli kredytów o podwyższonym ryzyku. Jeszcze w 2002 roku udział tego typu kredytów w ogólnej ilości udzielonych kredytów hipotecznych wynosił około $6 \%$, jednak na przełomie lat 2003/04 ich udział zaczął szybko rosnąc i w roku 2006 osiągnął prawie $25 \%$ ogółu 4 .

Obniżka stóp procentowych miała jeszcze jeden poważny skutek - spadek rentowności obligacji skarbowych. Dlatego też inwestorzy, którzy do tej pory inwestowali w obligacje skarbowe, zrezygnowali z tego i zaczęli szukać alternatywy, która byłaby równie bezpieczna, ale przynosiłaby wyższe stopy zwrotu. Taką możliwość zapewnił im rozwinięty rynek instrumentów pochodnych, tworząc obligacje zabezpieczane długiem (CDO). CDO to instrumenty, które powstają w procesie sekurytyzacji długów i dłużnych papierów wartościowych. Za aktywa bazowe, z których skonstruowany jest CDO, służą m.in. pożyczki korporacyjne, dłużne papiery wartościowe czy instrumenty, które powstały w procesie sekurytyzacji ${ }^{5}$. CDO w teorii pozwala zmniejszyć ryzyko, ponieważ sam instrument nie jest zależny od jednego długu, ale od wielu niewielkich części różnych długów. W praktyce możliwa jest jednak sytuacja, w której ryzyko danego instrumentu będzie bardzo trudne do oceny, kiedy przy tworzeniu CDO sekurytyzuje się powtórnie niektóre jego aktywa bazowe ${ }^{6}$. Emisja CDO pozwalała instytucjom finansowym na pozbycie się ryzyka związanego z udzielaniem kredytów subprime, stąd największa emisja tych instrumentów przypadała na lata, w których udzielano największej ilości kredytów podwyższonego ryzyka. Instytucje udzielające kredytów subprime tworzyły z nich następnie

${ }^{3}$ M. Lubiński, Międzynarodowa transmisja koniunktur a zarażenie, [w:] Nowe oblicza cyklu koniunkturalnego, red. R. Barczyk, L. Kąsek, M. Lubiński, K. Marczewski, Polskie Wydawnictwo Ekonomiczne, Warszawa 2016, s. 108-109.

${ }^{4}$ Federal Reserve of San Francisco, The Subprime Mortgage Market. National and Twelfth District Developments, Annual Report, 2007, s. 8.

${ }^{5} \mathrm{M}$. Buszko, Rynek produktów strukturyzowanych CDO w warunkach światowego kryzysu finansowego, Acta Universitatis Nicolai Copernici, Ekonomia XLI - Nauki Humanistyczno-Społeczne, Zeszyt 397, Toruń 2010, s. 143.

${ }^{6}$ Ibidem, s. 151. 
instrumenty CDO i po ocenie przez agencje ratingowe gotowy produkt był sprzedawany inwestorom. W ten sposób ryzyko związane z kredytem podwyższonego ryzyka nie było ponoszone przez instytucję, która tego kredytu udzieliła, a przenoszone na innych uczestników. Proces ten niejako łączył inwestorów oraz osoby, które zaciągały kredyty hipoteczne.

Ponieważ ciężko było dokładnie wycenić ryzyko związane z CDO, a agencje ratingowe przyznawały wielu z nich najwyższe lub bardzo wysokie oceny, instrumenty te były obracane na rynkach finansowych z całego świata jako jedna z bezpieczniejszych inwestycji, natomiast CDO z niską oceną trafiały głównie do funduszy hedgingowych. Instrumenty te nie były tak bezpieczne, jak się wydawało, ponieważ ich wartość była silnie skorelowana z rynkiem nieruchomości w USA ${ }^{7}$. Dopóki na rynku nieruchomości panował optymizm, a kredyty hipoteczne były spłacane CDO - były bezpieczną inwestycją, jednak w momencie, kiedy zdano sobie sprawę, że na rynku nieruchomości urosła ,bańka spekulacyjna", CDO zaczęły tracić na wartości, podobnie jak domy. Lawina ruszyła, gdy kredyty subprime przestały być spłacane. W reakcji na to banki, które udzieliły tychże kredytów, przejmowały nieruchomości, które następnie były wystawiane na sprzedaż. Duża podaż nieruchomości spowodowała spadek ich wartości, a spadające ceny domów doprowadziły do tego, że nawet kredytobiorcy, którzy mieli środki na spłatę kredytów, przestali je spłacać, gdyż wielkość kredytu w wielu przypadkach zaczęła przekraczać wartość zakupionej nieruchomości. W ten sposób problem jeszcze bardziej się pogłębił i nawet instrumenty z najwyższym ratingiem, czyli teoretycznie najbezpieczniejsze, traciły na wartości. Ze względu na to, że instrumenty te były uznawane za bezpieczne wiele instytucji finansowych miało je w swoich aktywach. Gdy CDO zaczęły tracić na wartości, instytucje, które były w ich posiadaniu, zaczęły ponosić straty. Ponieważ na rynku panowała dezinformacja, podmioty nie były przekonane, które z instytucji mogą stać się niewypłacalne na skutek strat, rynek pożyczek skurczył się. Podsumowując, można przyjąć, że spadek płynności na rynku międzybankowym był efektem wzrostu ilości niespłacanych kredytów subprime ${ }^{8}$.

Korekta wyceny ryzyk wystąpiła na kilku płaszczyznach. Między innymi wzrosło ryzyko pożyczek międzybankowych, co miało bezpośredni wpływ na „wyschnięcie” rynku kredytowego. Korekta wyceny ryzyk odnosiła się również do instrumentów finansowych oraz papierów wartościowych. Szczególnym rodzajem papierów wartościowych, które teoretycznie powinny być bardzo

7 P. Mizen, The Credit Crunch of 2007-2008: A Discussion of the Background, Market Reactions, and Policy Responses, Federal Reserve Bank of St. Louis Review, 90(5), September/October 2008, s. 532.

${ }^{8}$ M.K. Brunnermeier, Deciphering the Liquidity and Credit Crunch 2007-2008, Journal of Economic Perspectives, 23, 1 - Winter 2009, s. 82. 
bezpieczne, są obligacje, jednak na skutek zawirowań na rynkach rentowność obligacji niektórych państw gwałtownie wzrosła. Tak stało się między innymi z obligacjami kilku państw strefy euro.

\section{Sytuacja budżetowa oraz fiskalna krajów PIIGS przed oraz w trakcie kryzysu}

$\mathrm{Na}$ etapie tworzenia Unii Europejskiej zadbano o wytyczne, którymi powinny kierować się kraje członkowskie, prowadząc politykę fiskalną. W Traktacie z Maastricht istnieje zapis mówiący, że: „Rządy państw członkowskich będą unikać nadmiernego deficytu budżetowego". Notacja ta miała być przestrzegana dzięki kontrolowaniu poziomu deficytu budżetowego oraz wysokości długu publicznego w relacji do PKB. Poziom deficytu oraz długu publicznego zostały określone w protokole do artykułu 104 Traktatu z Maastricht. Ich wysokość ustanowiono na poziomie odpowiednio 3\% dla deficytu oraz $60 \%$ dla długu publicznego. Kontrola nad przestrzeganiem przepisów została powierzona Komisji Europejskiej, która w razie nieprawidłowości miała raportować do Rady Europejskiej. Rada Europejska po zapoznaniu się z raportem i stwierdzeniu nieprawidłowości mogła wszcząć procedurę naprawczą, w ramach której udzielano wskazówek co do naprawy sytuacji budżetowej. W przypadku „uporczywego" niestosowania się do zaleceń Rada miała prawo zastosować środki zaradcze, włącznie z zastosowaniem kary finansowej. W praktyce jednak unikano karania krajów.

Część krajów, które miały największe problemy z długiem publicznym oraz deficytem budżetowym, w trakcie kryzysu w strefie euro została potocznie określona niezbyt kulturalnym mianem PIIGS. Do grona krajów należały, kolejno od pierwszych liter angielskich nazw państw: Portugalia (Portugal), Włochy (Italy), Irlandia (Ireland), Grecja (Greece) oraz Hiszpania (Spain). Wydaje się jednak, że Irlandia oraz Hiszpania nie do końca „zasłużyły sobie” na bycie w tym niechlubnym gronie. Kraje te do roku 2007 starały się utrzymywać deficyt na niskim poziomie. Od roku 1995 do roku 2007 średni deficyt Hiszpanii wynosił $2,4 \%$ PKB, a więc poniżej progu $3 \%$, natomiast Irlandia notowała średnio 1,2\% PKB nadwyżki budżetowej. Można więc uznać, że przed wystąpieniem kryzysu obydwa kraje przestrzegały dyscypliny budżetowej ustalonej w Traktacie z Maastricht. Zgoła inaczej sytuacja wyglądała w pozostałych krajach badanej grupy. We Włoszech deficyt budżetowy w badanym okresie wynosił 3,5\% PKB, w Portugalii 4,3\% PKB, natomiast w Grecji aż 6,7\% PKB, czyli ponad dwukrotnie przekraczał ustaloną normę. Na wykresie 1 przedstawiono

${ }^{9}$ Zob. art. 104c Traktatu o Unii Europejskiej. 
kształtowanie się sald budżetów dla pięciu badanych krajów oraz dla 17 krajów strefy euro ${ }^{10} \mathrm{w}$ latach $1995-2015$.

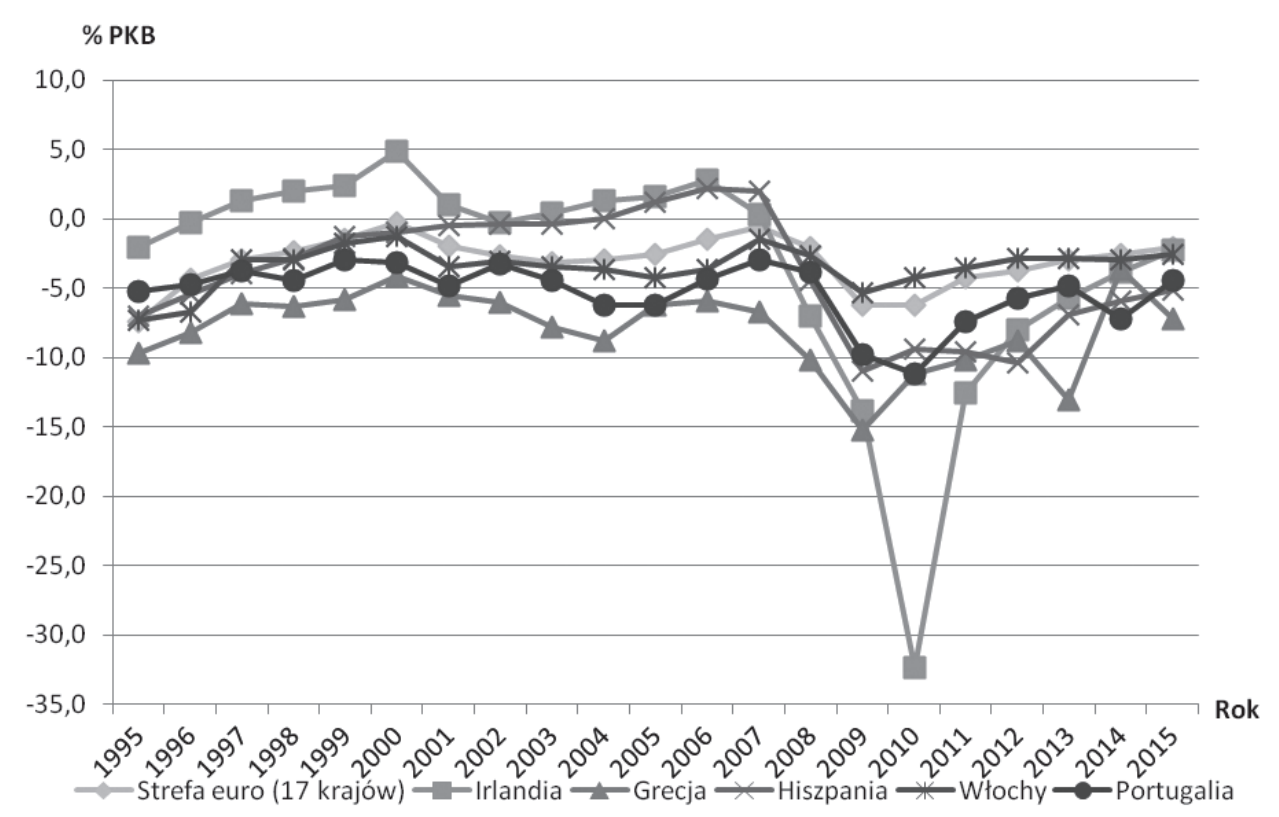

Wykres 1. Saldo budżetów w latach 1995-2015 jako procent PKB

Źródto: opracowanie wlasne na podstawie danych Eurostat.

W roku 2008 deficyty państw zwiększyły się, głównie ze względu na spadek aktywności gospodarczej. Dynamika PKB we wszystkich badanych krajach zmniejszyła się, natomiast gospodarki Grecji, Włoszech oraz Irlandii w latach 2008-2009 skurczyły się. Spadek aktywności gospodarczej miał wpływ na spadek dochodów budżetowych. Ponadto większe sumy z budżetu były przeznaczane na świadczenia socjalne, takie jak zasiłki dla bezrobotnych, co także przyczyniło się do pogorszenia sytuacji fiskalnej w badanych krajach.

Kolejnym kryterium, którego kraje członkowskie powinny przestrzegać w trosce o stan swoich finansów publicznych, było kryterium budżetowe. Wykres 2 prezentuje wysokość zadłużenia publicznego w relacji do PKB.

${ }^{10}$ Strefa euro liczy aktualnie 19 członków. W 2014 roku dołączyła Litwa, a w 2015 Łotwa. Ze względu na tak późną akcesję kraje te zostały pominięte w porównaniu. 


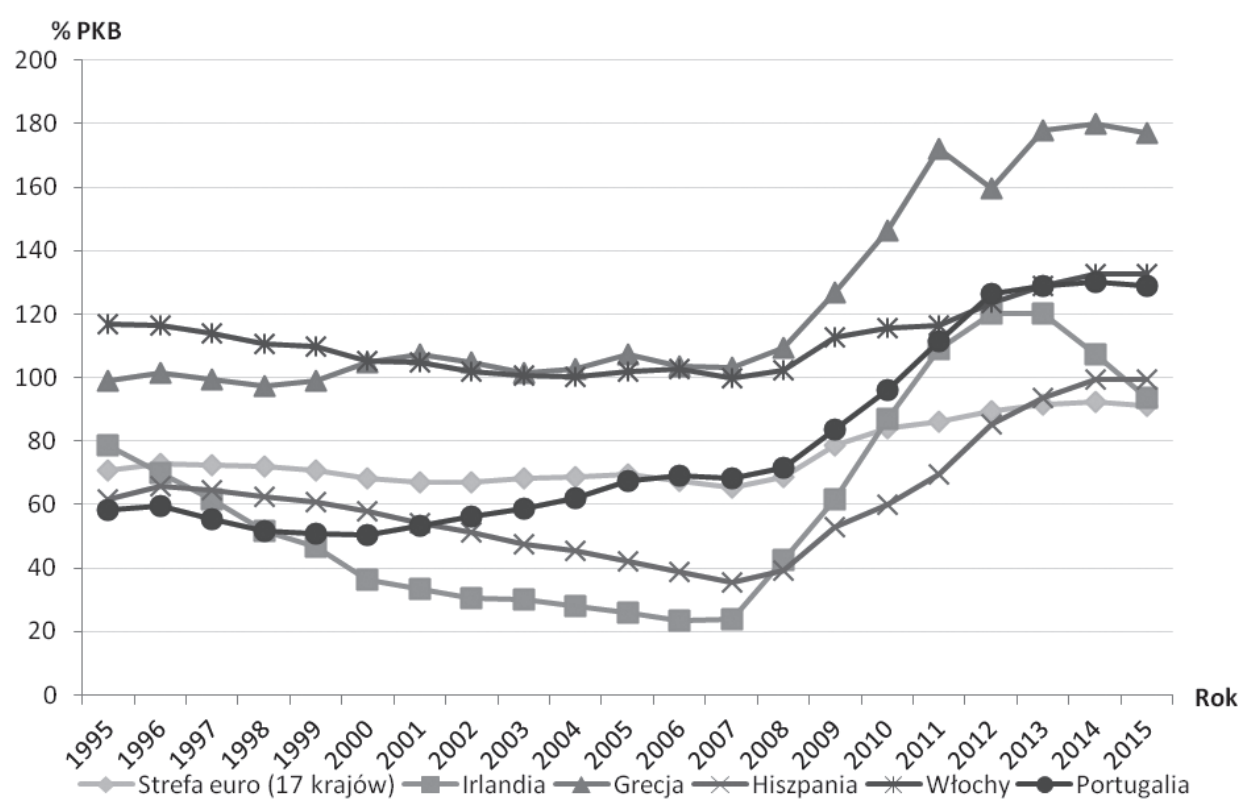

Wykres 2. Dług publiczny w relacji do PKB

Źródto: opracowanie własne na podstawie danych Eurostat.

Podobnie jak to było przy kryterium deficytu również w przypadku dyscypliny zadłużeniowej można rozróżnić kraje, które przestrzegały wyznaczonego kryterium, oraz te, które się do przepisów nie stosowały. Ponownie Irlandię oraz Hiszpanię można wyodrębnić jako kraje, które dbały o ten aspekt swoich finansów, natomiast Grecję czy Włochy można uznać za państwa, dla których wysokie zadłużenie jest problemem chronicznym. Już od początku badanego okresu zadłużenie Włoch znacznie przekraczało 100\% PKB, natomiast zadłużenie Grecji oscylowało wokół tej wartości. Włochom tuż przed wejściem do strefy euro udało się obniżyć zadłużenie do ok. 100\% PKB, jednak biorąc pod uwagę, że kryterium wynosiło $60 \%$ kraj ten można uznać za znacznie zadłużony. W nieco innej sytuacji była Portugalia. Przed wejściem do strefy euro kraj ten starał się obniżać swój dług publiczny, jednak od momentu wstąpienia

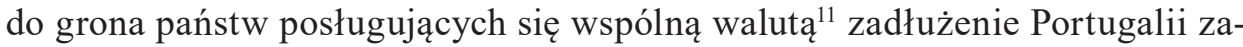
częło wzrastać. Można więc przyjąć, ze Portugalia obniżała swoje zadłużenie tylko ze względu na dostosowanie swojego kraju do wymogów stawianych przed przystąpieniem do strefy euro.

11 Walutą euro zaczęto się posługiwać w 1999 roku w rozliczeniach międzypaństwowych, natomiast gotówka została wprowadzona do obiegu w roku 2001. 


\section{Specyficzna sytuacja Irlandii oraz Hiszpanii}

Kryzys, którego początek przypadał na lata 2007-2008 w Hiszpanii oraz Irlandii, poprzedzony był „bańkami spekulacyjnymi” na tamtejszych rynkach nieruchomości. W Hiszpanii podaż kredytów hipotecznych między rokiem 2002 a rokiem 2007 uległa niemalże potrojeniu, a podaż kredytów związanych z działalnością deweloperską zwiększyła się sześciokrotnie ${ }^{12}$. Natomiast w Irlandii podaż kredytów hipotecznych wzrosła między rokiem 2001 a rokiem 2006 prawie pięciokrotnie ${ }^{13}$. Ze względu na silne międzynarodowe powiązania instytucji finansowych i ich pewnego rodzaju ,uzależnienie” od finansowania zagranicznego spowodowało problemy, kiedy rynek pożyczek międzybankowych zamarł. Dodatkowo instytucje finansowe miały w swoich bilansach znaczne ilości papierów, które były silnie skorelowane z cenami nieruchomości, zatem pęknięcie „baniek spekulacyjnych” spowodowało znaczące straty banków irlandzkich oraz hiszpańskich.

W celu załagodzenia sytuacji w obydwu krajach rządy Irlandii oraz Hiszpanii wdrożyły programy pomocowe, które znacząco obciążały budżety obu krajów. Irlandzki rząd w porozumieniu z Komisją Europejską powołał Agencję ds. Zarządzania Majątkiem Narodowym (ang. National Asset Management Agency, NAMA), która od 2009 roku miała za zadanie przejmować „toksyczne aktywa” od irlandzkich instytucji finansowych ${ }^{14}$. Ponadto irlandzki rząd zdecydował się na wykupienie udziałów oraz dokapitalizowanie części instytucji finansowych. Działania te kosztowały ok. 60-80 mld EUR ${ }^{15}$.

Rząd Hiszpanii rozpoczął program pomocy dla banków w 2008 roku. Obejmował on między innymi zwiększenie gwarancji depozytów, gwarancje rządowe na zobowiązania oraz długi banków, a także ich rekapitalizację. Władze Hiszpańskie utworzyły Fundusz Uporządkowanej Restrukturyzacji Banków (hiszp. The Fondo de Restructuración Ordenada Bancaria; FROB), który dysponował kapitałem 99 mld EUR, a do jego zadań należała między innymi restrukturyzacja banków oraz zapobieganie destabilizacji systemu ${ }^{16}$.

${ }^{12}$ International Monetary Fund, Spain: Selected Issues, IMF Country Report No. 11/216, 2011, s. 7.

${ }^{13}$ G. Kennedy, T. McIndoe-Calder, The Irish Mortgage Market: Stylised Facts, Negative Equity and Arrears, Central Bank Quarterly Bulletin, Central Bank of Ireland, January 2012, s. 91.

${ }_{14}$ B. Michalski, Kryzys irlandzki. Jak i dlaczego celtycki tygrys stracił swoją drapieżność?, [w:] Kryzys i perspektywy strefy euro, red. J. Rymarczyk, M. Wróblewski, D. Brzęczek-Nester, Międzynarodowe Stosunki Gospodarcze. Aktualne Problemy VIII, Wrocław 2014, s. 100.

${ }^{15}$ Ibidem, s. 101.

${ }^{16}$ M. Golańska-Płuciennik, Kryzys w Hiszpanii, [w:] Kryzys i perspektywy strefy euro, s. $155-156$. 


\section{Bezpośrednia pomoc finansowa udzielona krajom strefy euro}

Globalny kryzys finansowy, który wybuchł w 2007 roku, a w Europie przerodził się w kryzys zadłużenia, doprowadził część krajów europejskich do poważnych problemów. Wzrost ryzyka na rynku, niepewność oraz zamarcie rynku pożyczkowego doprowadziły do wzrostu oprocentowania obligacji krajów, które uznane zostały za najbardziej zagrożone bankructwem. Wykres 3 przedstawia oprocentowanie dziesięcioletnich obligacji wybranych krajów strefy euro w latach 1997-2015.

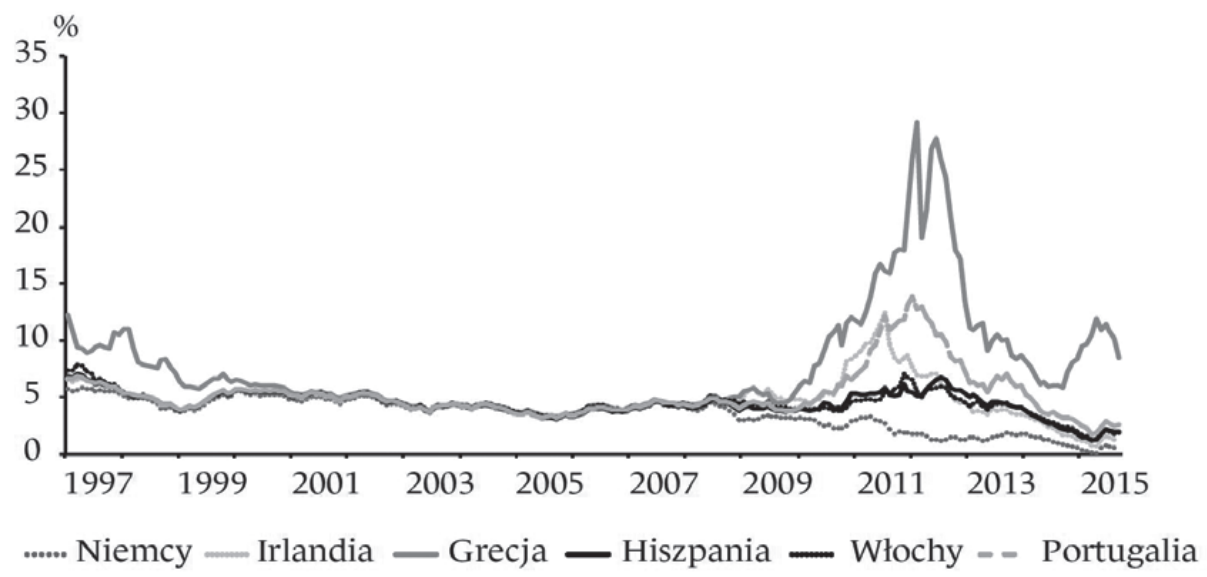

Wykres 3. Oprocentowanie dziesięcioletnich obligacji skarbowych

Źródto: W. Grabowski, E. Stawasz, Determinanty rentowności obligacji skarbowych peryferyjnych krajów strefy euro w warunkach stabilności i kryzysu, Bank i Kredyt, 47(2), 2016.

Lata 2001-2008 były okresem względnej stabilności oraz konwergencji oprocentowania obligacji krajów strefy euro. Jak wskazywał Europejski Bank Centralny, następująca zbieżność oprocentowania długoterminowych obligacji skarbowych krajów strefy euro była spowodowana wprowadzeniem wspólnej waluty oraz idącą za tym eliminacją ryzyka kursowego ${ }^{17}$. Kolejnym czynnikiem sprzyjającym konwergencji oprocentowania długoterminowych obligacji skarbowych była z pewnością jednolita stopa procentowa wyznaczana przez EBC. Wydaje się, że nie bez znaczenia pozostawać może również przekonanie, że kraje będące w strefie euro są ze sobą ściślej związane, co oznacza, że w razie wystąpienia problemów w jednym z krajów pozostałe w trosce o stabilność wspólnej waluty ruszą mu na ratunek.

${ }^{17}$ European Central Bank, Monthly Bulletin, November 2003, s. 22. 
W momencie wystąpienia kryzysu zdano sobie sprawę, że de facto ryzyko może być zróżnicowane dla poszczególnych papierów. Pojawiły się również pogłoski o możliwości wystąpienia Grecji ze strefy euro, co poddawało w wątpliwość zapewnienia, że unia walutowa pozostanie integralna. Dodatkowo brak płynności na rynkach finansowych spowodował, że dostępność kapitału była mniejsza, co zmuszało kraje do oferowania wyższego wynagrodzenia za udostępnione środki finansowe. Wszystkie te zjawiska spowodowały, że oprocentowanie obligacji krajów mających problemy budżetowe znacznie się zwiększyły. Oprocentowanie greckich papierów wzrosło sześciokrotnie, a portugalskich i irlandzkich niemal trzykrotnie. Z drugiej strony wielu inwestorów szukało tak zwanej „,bezpiecznej przystani”, czyli inwestycji, które pozwalały zarabiać mniej, ale cechowały się mniejszym ryzykiem. Stąd spadek oprocentowania obligacji niemieckich widoczny na wykresie, umocnienie franka szwajcarskiego ${ }^{18}$ czy znaczny wzrost cen złota.

W reakcji na rosnący niepokój politycy europejscy powołali do życia kilka instytucji, których zadaniem była bezpośrednia pomoc oraz stabilizacja finansowa krajów mających największe problemy. Działalność tychże instytucji miała również doprowadzić do spadku oprocentowania papierów zagrożonych krajów, co mogło zostać zapewnione w dwojaki sposób. Z jednej strony chciano rozwiać wątpliwości inwestorów co do ryzyka inwestycji w obligacje zagrożonych państw. Pomoc finansowa oddalała widmo bankructwa, przez co ryzykowność zakupu papierów dłużnych malała. $Z$ drugiej strony popyt na pożyczki z rynku prywatnego malał, ponieważ część zobowiązań zagrożonych państw była pokrywana z pomocy nowo powołanych instytucji.

W maju 2010 roku Rada do Spraw Gospodarczych i Finansowych (ang. Economic and Financial Affairs Council, ECOFIN) powołała dwie instytucje - Europejski Mechanizm Stabilizacji Finansowej (ang. European Financial Stabilization Mechanism, EFSM) oraz Europejski Instrument Stabilności Finansowej (ang. European Financial Stability Facility, EFSF) jako rozwiązanie tymczasowe ${ }^{19}$. Zakres zobowiązań gwarancyjnych EFSF oraz EFSM sięgał 780 mld EUR ${ }^{20}$. Do bezpośrednich celów nowo powołanych instytucji należało wzmocnienie stabilności finansowej krajów strefy euro oraz wspieranie finansowe państw unii walutowej. W celu realizacji swoich zadań EFSF otrzymał możliwość emitowania obligacji oraz innych instrumentów dłużnych na potrzeby pozyskania funduszy, interwencji na pośrednim

18 W reakcji na znaczny wzrost wartości franka w 2011 roku Szwajcarski Bank Centralny usztywnił kurs franka do euro na poziomie 1,2 CHF = 1 EUR. W styczniu 2013 roku ogłoszono, że SNB nie będzie dłużej interweniował w celu obrony wyznaczonego kursu, co natychmiastowo poskutkowało znaczącą aprecjacją szwajcarskiej waluty.

19 B. Grabińska, Pomoc finansowa dla państw strefy euro dotkniętych kryzysem zadtużenia, Zeszyty Naukowe Uniwersytetu Ekonomicznego w Krakowie, 8(932), Kraków 2014, s. 36-37.

${ }^{20}$ Narodowy Bank Polski, Informacja na temat nowych zasad funkcjonowania Europejskiego Instrumentu Stabilności Finansowej (EFSF) oraz przyszłego kształtu Europejskiego Mechanizmu Stabilności (ESM), Warszawa, sierpień 2011, s. 2. 
oraz bezpośrednim (w wyjątkowych sytuacjach) rynku długu, pomocy finansowej w oparciu o program dostosowawczy, a także możliwość udzielania pożyczek w celu dokapitalizowania instytucji finansowych ${ }^{21}$. Tabela 1 przedstawia łączne kwoty wsparcia finansowego udzielonego poszczególnym krajom w latach 2011-2015.

Tabela 1. Kwoty wsparcia dla poszczególnych krajów w ramach EFSF

\begin{tabular}{|c|c|c|c|}
\hline Rok & Portugalia & Irlandia & Grecja \\
\hline $\mathbf{2 0 1 1}$ & 6,9 mld $€$ & $7,6 \mathrm{mld} €$ & - \\
\hline $\mathbf{2 0 1 2}$ & $11,3 \mathrm{mld} €$ & $4,4 \mathrm{mld} €$ & $108,2 \mathrm{mld} €$ \\
\hline $\mathbf{2 0 1 3}$ & $6,6 \mathrm{mld} €$ & $5,7 \mathrm{mld} €$ & $25,3 \mathrm{mld} €$ \\
\hline $\mathbf{2 0 1 4}$ & $1,2 \mathrm{mld} €$ & - & $8,3 \mathrm{mld} €$ \\
\hline $\mathbf{2 0 1 5}$ & - & - & $-10,9 \mathrm{mld} €$ \\
\hline Suma & $26 \mathrm{mld} €$ & $17,7 \mathrm{mld} €$ & $130,9 \mathrm{mld} €$ \\
\hline
\end{tabular}

Źródto: opracowanie własne na podstawie danych EFSF: http://www.efsf.europa.eu/about/operations/index.htm [dostep: 16.06.2016].

W ramach EFSF wsparcie finansowe otrzymała Portugalia, Irlandia oraz Grecja w kwotach kolejno: 26 mld EUR, 17,7 mld EUR oraz 141,8 mld EUR. W roku 2015 Grecja oddała niesprzedane obligacje wyemitowane przez EFSF o wartości 10,9 mld EUR, co zmniejszyło całkowitą kwotę pomocy do 130,9 mld EUR. Łącznie pomoc dla wszystkich wymienionych krajów w ramach EFSF kosztowała 174,6 mld EUR. Jedynie Portugalia oraz Irlandia otrzymały pomoc w ramach Europejskiego Mechanizmu Stabilizacji Finansowej. Tabela 2 przedstawia sumę tejże pomocy w latach 2011-2014.

Tabela 2. Pomoc udzielona poszczególnym krajom w ramach EFSM

\begin{tabular}{|c|c|c|}
\hline Rok & Portugalia & Irlandia \\
\hline $\mathbf{2 0 1 1}$ & $14,1 \mathrm{mld} €$ & 13,9 mld $€$ \\
\hline $\mathbf{2 0 1 2}$ & 8 mld $€$ & 8,8 mld $€$ \\
\hline $\mathbf{2 0 1 4}$ & $2,2 \mathrm{mld} €$ & 0,8 mld $€$ \\
\hline Suma & 24,3 mld $€$ & 23,5 mld $€$ \\
\hline
\end{tabular}

Źródto: opracowanie własne na podstawie danych Komisji Europejskiej: http://ec.europa.eul economy_financeleu_borrowerlefsm/index_en.htm [dostęp: 16.06.2016].

${ }^{21}$ Biuro Pełnomocnika Rządu ds. Wprowadzenia Euro przez Rzeczpospolitą Polską, Ministerstwo Finansów, Co to jest EFSF i ESM?, www.mf.gov.pl/documents/764034/1417826/23_efsf-esm. pdf [dostęp: 21.06.2016]. 
W latach 2011-2014 Portugalia otrzymała wsparcie w wysokości 24,3 mld EUR, natomiast Irlandia otrzymała 23,5 mld EUR, przy czym w każdym przypadku ponad połowa kwot przekazana została w roku 2011. W roku 2013 żaden z krajów nie otrzymał wsparcia. Łącznie w latach 2011-2014 w ramach EFSM krajom przekazano pomoc wartą 47,8 mld EUR.

W marcu 2011 roku mechanizmy powołane jako rozwiązanie tymczasowe zostały decyzją Rady Europejskiej zastąpione przez stały mechanizm - Europejski Mechanizm Stabilności (ang. European Stability Mechanism, ESM). Całkowity kapitał subskrybowany ESM wynosi 700 mld EUR, z czego 80 mld zostało wniesione na etapie jego tworzenia, natomiast pozostała część ma charakter kapitału na żądanie, czyli będzie przekazana do mechanizmu w razie potrzeby ${ }^{22}$.

Tabela 3. Calkowita pomoc udzielona krajom w ramach mechanizmu ESM

\begin{tabular}{|c|c|c|}
\hline Rok & Grecja & Hiszpania \\
\hline $\mathbf{2 0 1 2}$ & - & $39,5 \mathrm{mld} €$ \\
\hline $\mathbf{2 0 1 3}$ & - & $41,3 \mathrm{mld} €$ \\
\hline $\mathbf{2 0 1 5}$ & $21,4 \mathrm{mld} €$ & v \\
\hline $\mathbf{2 0 1 6}$ & $7,5 \mathrm{mld} €$ & - \\
\hline Suma & $28,9 \mathrm{mld} €$ & $80,8 \mathrm{mld} €$ \\
\hline
\end{tabular}

Źródło: opracowanie własne na podstawie danych ESM: http://www.esm.europa.eu/assistancel index.htm [dostęp: 16.06.2016].

Poza pomocą finansową w ramach utworzonych europejskich mechanizmów wybrane kraje otrzymały również pomoc od Międzynarodowego Funduszu Walutowego, choć początkowo część krajów europejskich była sceptyczna co do tego rozwiązania. Uznawano bowiem, że włączenie zewnętrznej instytucji do programów pomocowych może być interpretowana jako słabość instytucji europejskich. Obawiano się, że może to doprowadzić do postrzegania strefy euro jako instytucji, która nie potrafi sama poradzić sobie z problemami ${ }^{23}$. Ostatecznie jednak zdecydowano się skorzystać ze wsparcia MFW ze względu na wieloletnie doświadczenie tej instytucji w pomocy finansowej. Z pomocy MFW skorzystały trzy kraje ${ }^{24}$ - Portugalia, Irlandia oraz Grecja, a łączna przekazana pomoc wyniosła 98,3 mld

${ }^{22}$ Narodowy Bank Polski, op. cit., s. 3.

${ }_{23}$ M. Koczor, Analiza tymczasowych rozwiazań ratunkowych/stabilizacyjnych przyjętych w strefie euro od 2010 roku, [w:] Hereditas Mercaturae, red. P. Czubik, Z. Mach, Instytut Multimedialny, Kraków 2012, s. 174.

${ }^{24} \mathrm{Z}$ pomocy MFW korzysta na co dzień więcej państw, więc w omówieniu brane są pod uwagę tylko kraje $\mathrm{z}$ badanej grupy. 
EUR. Dane na temat pomocy udzielonej poszczególnym krajom przez MFW znajdują się w Tabeli 4.

Tabela 4. Pomoc udzielona poszczególnym krajom przez MFW w latach 2011-2016

\begin{tabular}{|c|c|}
\hline Kraj & Wysokość udzielonej pomocy \\
\hline Portugalia & $26 \mathrm{mld} €$ \\
\hline Irlandia & $22,5 \mathrm{mld} €$ \\
\hline Grecja & $49,8 \mathrm{mld} €$ \\
\hline Suma & $98,3 \mathrm{mld} €$ \\
\hline
\end{tabular}

Źródło: opracowanie własne na podstawie: B. Grabińska, Pomoc finansowa dla państw strefy euro dotkniętych kryzysem zadtużenia, Zesz. Nauk. UEK, 2014.

W badanym okresie spośród badanej grupy państw z różnego rodzaju pomocy finansowej skorzystała Grecja, Hiszpania, Irlandia oraz Portugalia. Pomoc udzielona Grecji była zdecydowanie największa i stanowiła niemal połowę z 430,4 mld EUR całkowitej wartości programów pomocowych.

Całkowita wysokość pomocy udzielonej zarówno przez MFW, jak i w ramach europejskich mechanizmów przypadająca na poszczególne kraje zaprezentowana jest w Tabeli 5. Jedynym krajem z opisanej grupy, który nie był zmuszony z takiej pomocy korzystać, były Włochy. Najprawdopodobniej nie było takiej potrzeby, ponieważ włoski deficyt od 2009 roku był najniższy wśród badanej grupy krajów, a należy pamiętać, że pomoc udzielona zarówno w ramach europejskich mechanizmów, jak i ta udzielona przez MFW jest długiem, który należy spłacić.

Tabela 5. Całkowita pomoc udzielona poszczególnym krajom w latach 2011-2016

\begin{tabular}{|c|c|}
\hline Kraj & Suma programów pomocowych \\
\hline Portugalia & $76,3 \mathrm{mld} €$ \\
\hline Irlandia & $63,7 \mathrm{mld} €$ \\
\hline Grecja & $209,6 \mathrm{mld} €$ \\
\hline Hiszpania & $80,8 \mathrm{mld} €$ \\
\hline Suma & $430,4 \mathrm{mld} €$ \\
\hline
\end{tabular}

Źródło: opracowanie własne na podstawie danych EFSF, Komisji Europejskiej, ESM oraz B. Grabińska, op. cit.

Powstaje jednak pytanie, czy nie lepiej byłoby zaciągać dług w ramach europejskich mechanizmów, zamiast szukać finansowania wśród inwestorów 
prywatnych, co miało miejsce, biorąc pod uwagę wzrost zadłużenia publicznego w latach 2008-2015 oraz mniej więcej stałą stopę oprocentowania włoskich obligacji we wspomnianym okresie.

\section{Podsumowanie i wnioski}

Bezpośrednią przyczyną kryzysu, który wybuchł w Europie, było załamanie gospodarcze w USA oraz jego szerokie konsekwencje dla branży finansowej. Papiery wartościowe, zmniejszenie się rynku kredytowego oraz ucieczka inwestorów w kierunku aktywów powszechnie uznawanych za bezpieczne, jak złoto czy obligacje silnych gospodarek, drastycznie wpłynęły przede wszystkim na sytuację krajów, które potrzebowały zewnętrznych źródeł finansowania. Należy zaznaczyć, że kraje zagrożone bankructwem były przed wystąpieniem kryzysu w bardzo różnych sytuacjach. O ile Irlandia czy Hiszpania potrzebowały pomocy ze względu na „bańkę spekulacyjną” na rynku nieruchomości, o tyle Grecja miała kłopoty przez wieloletnie zaniedbania dyscypliny fiskalnej i życie „na kredyt”.

Decydenci Unii Europejskiej wykazali niezwykłą determinację w ratowaniu zagrożonych gospodarek. Efekty są jednak zróżnicowane. Trzeba przyznać, że Irlandia po przeprowadzeniu reform wraca na ścieżkę wzrostu, a jej zadłużenie oraz deficyt budżetowy z roku na rok maleją. Przykładem niewątpliwie marnych skutków pomocy jest Grecja. Kraj ten coraz bardziej pogrąża się w długach, a od początku uruchomienia środków pomocowych nie widać znaczącej poprawy sytuacji gospodarczej. Należałoby się zastanowić, czy warto było angażować tak wielkie środki na cele pomocowe. $Z$ jednej strony upadek Grecji oraz idący za nim „Grexit" byłyby problemem nie tylko dla samej strefy euro, ale również dla całej Unii Europejskiej. Z drugiej strony bezustanna pomoc, która nie przynosi rezultatów, jest obciążeniem dla europejskich społeczeństw za błędy, których one nie popełniły. Ewentualne wyjście Grecji ze strefy euro według przewodniczącego Parlamentu Europejskiego byłoby równoznaczne z opuszczeniem całej Unii Europejskiej25. $\mathrm{Z}$ jednej strony odejście z tak dużej strefy wolnego przepływu kapitału, usług czy osób byłoby problemem dla podmiotów, których powodzenie gospodarcze zależy w dużej mierze od tych kontaktów. $Z$ drugiej strony powrót do drachmy pozwoliłby na pewien czas odzyskać Grecji konkurencyjność. Podmioty zaangażowane w pomoc Grecji tracą bez względu na to, czy kraj ten będzie nadal utrzymywany przez pożyczki, czy też opuści strefę euro, bankrutując. Trudno jest więc ocenić, czy dalsza pomoc jest uzasadniona ekonomicznie. Być może lepiej byłoby, gdyby

${ }^{25}$ B. Ehrenberg, CITY A.M., Grexit from the euro means Greece will also have to leave the EU says Martin Schulz, as Athens claims ball is in creditors' court, 18.06.2015, http://www.cityam. com/218262/grexit-euro-means-greece-will-also-have-leave-eu-says-martin-schulz-athens-says-ball [dostęp: 13.07.2016]. 
decydenci opracowali rozwiązanie, dzięki któremu Grecja będzie w stanie pozostać w UE, rezygnując jednak ze wspólnej waluty. Wpłynęłoby to niewątpliwe źle na rynek, jednak byłoby to doświadczenie jednorazowe, zamiast przeciągającego się stanu nerwowości i niepewności, jaki towarzyszy europejskim gospodarkom oraz inwestorom od 2007 roku. Jednakże ze względu na sytuację polityczną po referendum w Wielkiej Brytanii takie rozwiązanie jest trudne do przyjęcia. Sytuacja w strefie euro i w całej Unii Europejskiej z wyjątkową mocą pokazuje, jak silne jest wzajemne uwarunkowanie procesów gospodarczych i politycznych.

\section{Bibliografia}

Biuro Pełnomocnika Rządu ds. Wprowadzenia Euro przez Rzeczpospolitą Polską, Ministerstwo Finansów, Co to jest EFSF i ESM?, www.mf.gov.pl/documents/764034/1417826/23_efsf-esm. pdf [dostęp: 21.06.2016].

Brunnermeier M.K., Deciphering the Liquidity and Credit Crunch 2007-2008, Journal of Economic Perspectives, 23, 1 - Winter 2009.

Buszko M., Rynek produktów strukturyzowanych CDO w warunkach światowego kryzysu finansowego, Acta Universitatis Nicolai Copernici, Ekonomia XLI - Nauki Humanistyczno-Społeczne, Zeszyt 397, Toruń 2010.

Chudik A., Fratzcher M., Identifying The Global Transmission of the 2007-09 Financial Crisis in a GVAR Model, ECB Working Paper Series No. 1285, 2011.

Ehrenberg, B., CITY A.M., Grexit from the euro means Greece will also have to leave the EU says Martin Schulz, as Athens claims ball is in creditors' court, 18.06.2015, http://www.cityam. com/218262/grexit-euro-means-greece-will-also-have-leave-eu-says-martin-schulz-athens-says-ball [dostęp: 13.07.2016].

European Central Bank, Monthly Bulletin, November 2003.

Federal Reserve of San Francisco, The Subprime Mortgage Market. National and Twelfth District Developments, Annual Report, 2007.

Gabrielczak P., Rola kanału handlowego i finansowego w zarażeniu państw rozwiniętych $i$ rozwijajacych się, Studia i prace Wydziału Nauk Ekonomicznych i Zarządzania, 3(41), 2015.

Golańska-Płuciennik M., Kryzys w Hiszpanii, [w:] Kryzys i perspektywy strefy euro, red. J. Rymarczyk, M. Wróblewski, D. Brzęczek-Nester, Międzynarodowe Stosunki Gospodarcze. Aktualne Problemy VIII, Wrocław 2014.

Grabińska B., Pomoc finansowa dla państw strefy euro dotkniętych kryzysem zadtuzenia, Zeszyty Naukowe Uniwersytetu Ekonomicznego w Krakowie, 8(932), 2014.

Grabowski W., Stawasz E., Determinanty rentowności obligacji skarbowych peryferyjnych krajów strefy euro $w$ warunkach stabilności i kryzysu, Bank i Kredyt, 47(2), 2016.

International Monetary Fund, Spain: Selected Issues, IMF Country Report No. 11/216, 2011.

Kennedy G., McIndoe-Calder T., The Irish Mortgage Market: Stylised Facts, Negative Equity and Arrears, Central Bank Quarterly Bulletin, Central Bank of Ireland, January 2012.

Koczor M., Analiza tymczasowych rozwiązań ratunkowych/stabilizacyjnych przyjętych $w$ strefie euro od 2010 roku, [w:] Hereditas Mercaturae, red. P. Czubik, Z. Mach, Instytut Multimedialny, Kraków 2012.

Lubiński M., Międzynarodowa transmisja koniunktur a zarażenie, [w:] Nowe oblicza cyklu koniunkturalnego, red. R. Barczyk, L. Kąsek, M. Lubiński, K. Marczewski, Polskie Wydawnictwo Ekonomiczne, Warszawa 2016. 
Michalski B., Kryzys irlandzki. Jak i dlaczego celtycki tygrys stracił swoją drapieżność?, [w:] Kryzys i perspektywy strefy euro, red. J. Rymarczyk, M. Wróblewski, D. Brzęczek-Nester, Międzynarodowe Stosunki Gospodarcze. Aktualne Problemy VIII, Wrocław 2014.

Mizen P., The Credit Crunch of 2007-2008: A Discussion of the Background, Market Reactions, and Policy Responses, Federal Reserve Bank of St. Louis Review, 90(5), September/October, 2008.

Narodowy Bank Polski, Informacja na temat nowych zasad funkcjonowania Europejskiego Instrumentu Stabilności Finansowej (EFSF) oraz przyszłego kształtu Europejskiego Mechanizmu Stabilności (ESM), Warszawa, sierpień 2011.

Strona internetowa Europejskiego Instrumentu Stabilności Finansowej, http://www.efsf.europa.eu [dostęp: 16.06.2016].

Strona internetowa Europejskiego Mechanizmu Stabilności, http://www.esm.europa.eu [dostęp: 16.06.2016].

Strona internetowa Komisji Europejskiej, http://ec.europa.eu [dostęp: 16.06.2016].

Traktat o Unii Europejskiej.

http://ec.europa.eu/economy_finance/eu_borrower/efsm/index_en.htm [dostęp: 16.06.2016].

http://www.efsf.europa.eu/about/operations/index.htm [dostęp: 16.06.2016].

\section{Streszczenie}

Kryzys, który rozpoczął się w 2007 roku w Stanach Zjednoczonych, sprawił, że część krajów strefy euro popadła w tarapaty. Niskie stopy procentowe oraz tani kredyt przyczyniły się do powstania „bańki spekulacyjnej” na rynku nieruchomości. Wiele międzynarodowych instytucji finansowych było silnie zaangażowany w rynek pożyczek oraz instrumentów pochodnych powiązanych z rynkiem nieruchomości, dlatego też w momencie załamania się tego rynku wiele z tych instytucji straciło stabilność finansową, a część z nich upadła. Inwestorzy zaczęli wycofywać swój kapitał z ryzykownych instrumentów i niektórych obligacji, inwestując w bezpieczniejsze aktywa. Spowodowało to kryzys płynności na międzynarodowym rynku finansowym, co miało wpływ na sytuację finansową części krajów europejskich. Dobrym przykładem jest Grecja, której budżet był oparty w dużej mierze o tanie pożyczki, dlatego w momencie wystąpienia kryzysu kraj ten stanął przed widmem bankructwa. W innych krajach, jak Irlandia czy Hiszpania, kryzys na ich własnych rynkach nieruchomości spowodował potrzebę ratowania instytucji finansowych, co silnie wpłynęło na wystąpienie problemów budżetowych. W następstwie tych wydarzeń Unia Europejska stworzyła kilka instrumentów finansowych, których zadaniem była pomoc zagrożonym krajom. W pomoc zaangażowany był także Międzynarodowy Fundusz Walutowy. Jednak nie we wszystkich przypadkach pomoc została właściwie wykorzystana. Sytuacja Irlandii znacząco się poprawiła, jednak Grecja wciąż boryka się z problemami budżetowymi. W tym przypadku być może lepszym rozwiązaniem byłoby pozwolenie na bankructwo Grecji oraz powrót do drachmy, aby uniknąć, jak się wydaje, niekończących się strat oraz, w dłuższej perspektywie, zmniejszyć niepewność panującą na rynkach.

Słowa kluczowe: kryzys finansowy, strefa euro, pomoc finansowa, kryzys rynku nieruchomości 